\title{
Infantile Refsum disease
}

INSERM

\section{Source}

INSERM. (1999). Orphanet: an online rare disease and orphan drug data base. Infantile Refsum disease. ORPHA:772

Infantile Refsum disease (IRD) is the mildest variant of the peroxisome biogenesis disorders, Zellweger syndrome spectrum (PBD- ZSS; see this term), characterized by hypotonia, retinitis pigmentosa, developmental delay, sensorineural hearing loss and liver dysfunction. Phenotypic overlap is seen between IRD and neonatal adrenoleukodystrophy (NALD) (see this term). 